\title{
Behavior of Mesenchymal Stem Cells Obtained From Dental Tissues: A Review of the Literature
}

\section{Comportamiento de células mesenquimales obtenidas de tejidos dentales: Revisión de literatura}

\author{
Mariné Ortiz-Magdaleno DDS, MSc, PhD1; Ana Isabel Romo-Tobías DDS1; \\ Fernando Romo-Ramírez DDS, MSc'; ;iana María Escobar DDS, MSc, PhD²; \\ Héctor Flores-Reyes DDS, MSc, PhD²; Amaury Pozos-Guillén DDS, MSc, PhD² \\ 1. Specialty in Aesthetic, Cosmetic, Restorative, and Implantological Dentistry, \\ Faculty of Dentistry, Autonomous University of San Luis Potosí, Mexico. \\ 2. Laboratory of Basic Science, Faculty of Dentistry, Autonomous University of San Luis Potosí, Mexico. \\ Correspondence to: Dra. Mariné Ortiz-Magdaleno - marine.ortiz@uaslp.mx \\ Received: 17-IX-2018 \\ Accepted: 9-X-2018 \\ Published Online First: 16-X-2018 \\ DOI: https://doi.org/10.15517/ijds.v0i0.34884
}

\section{ABSTRACT}

The success of tissue engineering in combination with tissue regeneration depends on the behavior and cellular activity in the biological processes developed within a structure that functions as a support, better known as scaffolds, or directly at the site of the injury. The cell-cell and cell-biomaterial interaction are key factors for the induction of a specific cell behavior, together with the bioactive factors that allow the formation of the desired tissue. Mesenchymal Stem Cells (MSC) can be isolated from the umbilical cord and bone marrow; however, the behavior of Dental Pulp Stem Cells (DPSC) has been shown to have a high potential for the formation of bone tissue, and these cells have even been able to induce the process of angiogenesis. Advances in periodontal regeneration, dentin-pulp complex, and craniofacial bone defects through the induction of MSC obtained from tooth structures in in vitro-in vivo studies have permitted the obtaining of clinical evidence of the achievements obtained to date.

\section{KEYWORDS}

Dental pulp stem cells; Tissue engineering; Regenerative medicine; Dental tissues; Mesenchymal Stem Cells; Scaffolds. 


\section{RESUMEN}

El éxito de la ingeniería de tejidos en combinación con la regeneración de tejidos depende del comportamiento y la actividad celular en los procesos biológicos desarrollados dentro de una estructura que funciona como soporte mejor conocida como andamio o directamente en el sitio de la lesión. La interación célula-célula y célula-biomaterial son factores claves para la inducción a un comportamiento célular específico junto con factores bioactivos que permitan la formación del tejido deseado. Las células troncales mesenquimales (MSCs) pueden ser aisladas del cordón umbilical y de la medula ósea, sin embargo, el comportamiento de las células troncales de pulpa dental (DPSCs) han demostrado tener un alto potencial para la formación de tejido óseo e incluso han logrado inducir el proceso de angiogénesis. Avances en la regeneración periodontal, complejo dentino-pulpar y defectos óseos craneofaciales a travez de la inducción de MSCs obtenidas de estructuras de dientes en estudios in vitro-in vivo han permitido obtener evidencia clínica de los logros obtenidos hasta el momento.

\section{PALABRAS CLAVE}

Células troncales de pulpa dental; Ingeniería de tejidos; Medicina regenerativa; Tejidos dentales; Células Mesenquimales; Andamios.

\section{INTRODUCTION}

Tissue engineering was described by Langer and Vacanti in 1990, and three basic elements are required, including scaffolds; cells, and biologically active molecules that stimulate the formation of functional tissues and that restore or improve damaged tissues, including complete organs $(1,2)$. In contrast, emerging regenerative medicine incorporates the self-healing procedure, consisting of the use of biological systems combined with biomaterials biologically accepted by the organism that function as supports allowing the reconstruction of damaged tissues (3).

Regenerative medicine and tissue engineering are terms that can be easily combined and are part of the clinical and therapeutic strategies utilized in current dentistry (4). The search for innovative treatments that optimize results and that increase the predictability and potential of success in regenerative treatments of dental tissues continues in research; the induction of the formation of new bone tissue, regeneration of the dentin-pulp complex, remineralization of the damaged enamel, mechanisms of caries repair, and periodontal tissues are part of the challenges remaining to be solved (5). Therefore, the objective of this review was to publicize the strategies that are being used by the scientific community based on the regenerative engineering of dental tissue for therapeutic purposes based on the behavior and activity of Mesenchymal Stem Cells (MSC) and Dental Pulp Stem Cells (DPSC).

\section{TRANSPLANTATION OF MESENCHYMAL STEM CELLS AND STORAGE CONDITIONS}

The first cellular lines established of MSC obtained from different structures of teeth were DPSC and Stem cells from Human Exfoliated Deciduous teeth (SHED) established by Gronthos et al., both with high potential for differentiation into other cell lineages $(6,7)$. It has been possible to obtain MSC derived from the Stem Cells from the Apical Papilla (SCAP) of the third molar, demonstrating its high potential for inducing the regeneration of dentin (8) and MSC obtained from the periodontal ligament (DPLSC) that are capable of developing a tissue similar to the union of the 
cement with the root surface (9), while Dental Follicle precursor Cells (DFC) have shown high osteogenic potential (10).

The transplantation of MSC obtained from dental tissues for therapeutic purposes in the dental area is a procedure that has been performed experimentally in vivo in animal models (rats, dogs, rabbits, and pigs), demonstrating high predictability of success; however, there is still little evidence to bring these experimental protocols to controlled clinical trials. Strategies based on cellular therapies consist, first, on isolating the cells, maintaining them, and treating them in vitro under certain experimental conditions induced with stimulating factors and bioactive molecules. Once the cell population is expanded and the desired cell density is available, they can be injected or inoculated in a scaffold for transplantation to the site of the injury (11) (Fig. 1).

Studies and scientific experiments perform continuous research in the regeneration of bone and poplar and dentin tissue, giving rise to a large number of biomaterials in the search for that possessing the best capacities and properties for induction of the desired tissue. The design of scaffolds from biomaterials with applications in the regeneration of dental tissues is widely extended. They have been manufactured using ceramics, polymers of synthetic and natural origin, nanogels loaded with particles of bioactive elements, nanofibrous scaffolds that mimic the structure of the extracellular matrix and that manage to induce tissue formation by modulating the response and behavior of MSC (12).

The role played by the behavior of the DPSC in the regeneration of bone tissue is regulated by the secretion of paracrine factors and signaling, deposition of extracellular matrix, and cell-cell and cell-biomaterial interaction, considered key factors in tissue engineering (Table 1). Studies have shown the high potential of DPSC in the regeneration of bone tissue (13-17) and in regenerative cartilage treatments (18). It has been demonstrated that implantation of PDLSC and DPSC directly into the site of the defect may maintain their MSC characteristics after in-vivo implantation (19). On the other hand, it has been possible to mix DPSC with hydroxyapatite and tricalcium-phosphate and filling bone defects in the calvaria of rats, showing higher values of calcification and Bone Mineral Density (BMD) (20). In recent years, the use of polymeric nanofibrous scaffolds has attracted attention due to the diameter of the fibers near the collagen fibers, one of the main components of the extracellular matrix. The nanofibers, composed of polydioxanone and halloysite nanotubes, have supported the adhesion and proliferation of Human derived Pulp Fibroblast Cells (HPFC); these scaffolds have been proposed as an alternative for regenerative endodontics (21). The use of scaffolds in collagen gels and inoculated with DPSC injected into calvarial defects of rats have demonstrated increased BMD when DPSC-seeded scaffolds were employed (22).

In recent years, the number of companies dedicated to the storage of the MSC of deciduous teeth has increased. These banks are in charge of storing the dental organs and harvesting the multipurpose stem cells that can be used to treat different diseases. The advantages of obtaining this type of cell is that they are obtained naturally between 6 and 12 years after deciduous teeth fall out naturally and that they may be used as minimally invasive treatment. Studies have been conducted to simplify and minimize the transport and storage conditions of deciduous teeth up to the time of obtaining the MSC in order to maintain and optimize the viability conditions of the cells $(23,24)$ (Fig. 2). Normally, to obtain and harvest pulp tissue requires fracturing the crown. Studies have proposed to cryopreserve the dental organs immediately after their dental exfoliation, performing laser perforations on the surface of the tooth, so that the cryopreservation agent penetrates the pulp 
chamber, avoiding the need to cultivate the pulp fresh teeth exhibit similarities in their morphology, tissue immediately and maintaining the dental immunophenotype, viability and proliferation (25), organ intact, reducing costs and working time. It and there is no statistically significant difference has been demonstrated that SHED cryopreserved in the expression of MSC markers in terms of for a certain time compared to those obtained from adipogenic and osteogenic differentiation (26).

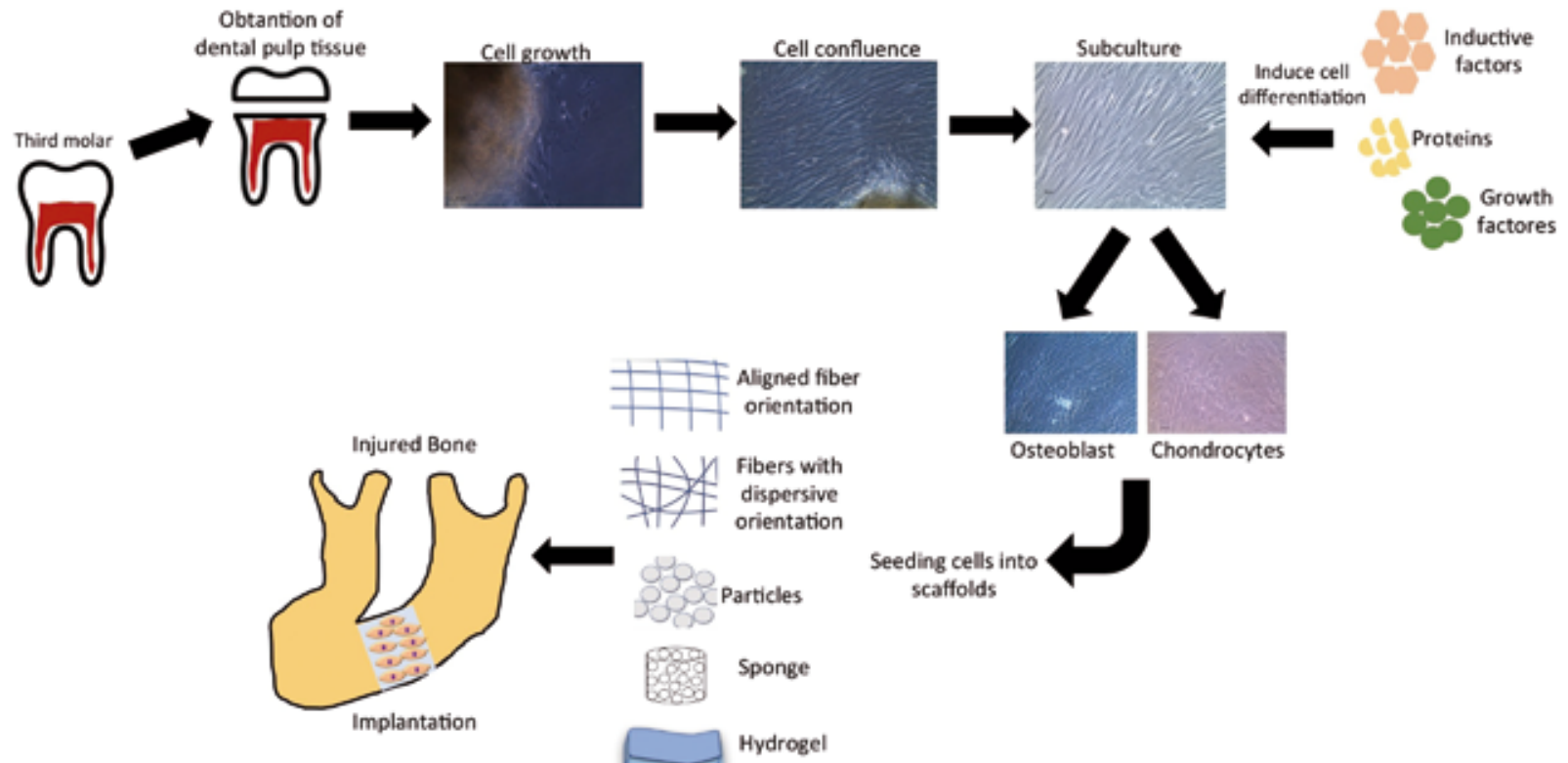

Fig. 1. Conventional protocol for tissue engineering and cells transplantation. 
Table 1. Studies referring to the application of Dental pulp mesenchymal stem cells (DPSCs) in tissue engineering, Periodontal dental ligament stem cells (PDLSCs), Porcine deciduous pulp stem (PDPSCs) and Gingival mesenchymal stem cells (GMSCs).

\begin{tabular}{cccc}
\hline Study & Year & Cell Line & Aplication \\
\hline Hernández M. B. et al. (39) & 2018 & DPSCs & Regenerative periodontal therapy \\
Fernandes T. L. et al. (18) & 2018 & DPSCs & Articular cartilage treatment \\
Itoh Y. et al. (28) & 2018 & DPSCs & Dental pulp regeneration \\
Fujii Y. et al. (13) & 2018 & DPSCs & Bone regenerative \\
Aimetti M. et al. (43) & 2018 & DPSCs & Treatment of periodontal intrabony defects \\
Tomasello L. et al. (14) & 2017 & DPSCs, GMSCs & Bone formation \\
Nakashima M. et al. (29) & 2018 & DPSCs & Pulp regeneration \\
Kouhestani F. et al. (15) & 2018 & DPSCs & Bone tissue engineering \\
Houshmand B. et al. (16) & 2018 & DPSCs & Bone regeneration \\
Yasui T. et al. (17) & 2017 & DPSCs & Bone regeneration \\
Piva E et al. (33) & 2017 & DPSCs & Dental pulp tissue regeneration \\
Bottino M. C. et al. (21) & 2015 & HPFCs & Regeneration of the pulp-dentine complex \\
Li X. et al. (31) & 2016 & DPSCs & Pulp regeneration \\
Chamieh F. et al. (22) & 2016 & DPSCs & Craniofacial bone regeneration \\
Asutay F. et al. (20) & 2015 & DPSCs & Bone regeneration \\
Dissanayaka W. L. et al. (32) & 2015 & DPSCs & Angiogenesis and pulp regeneration \\
Lei M. et al. (19) & 2014 & DPSCs, PDLSCs & Dental tissue \\
Zhu W et al. (30) & 2013 & DPSCs & Regeneration of dental pulp tissue \\
Zheng Y. et al. (35) & 2012 & PDPSCs & Dentin regeneration \\
\hline
\end{tabular}

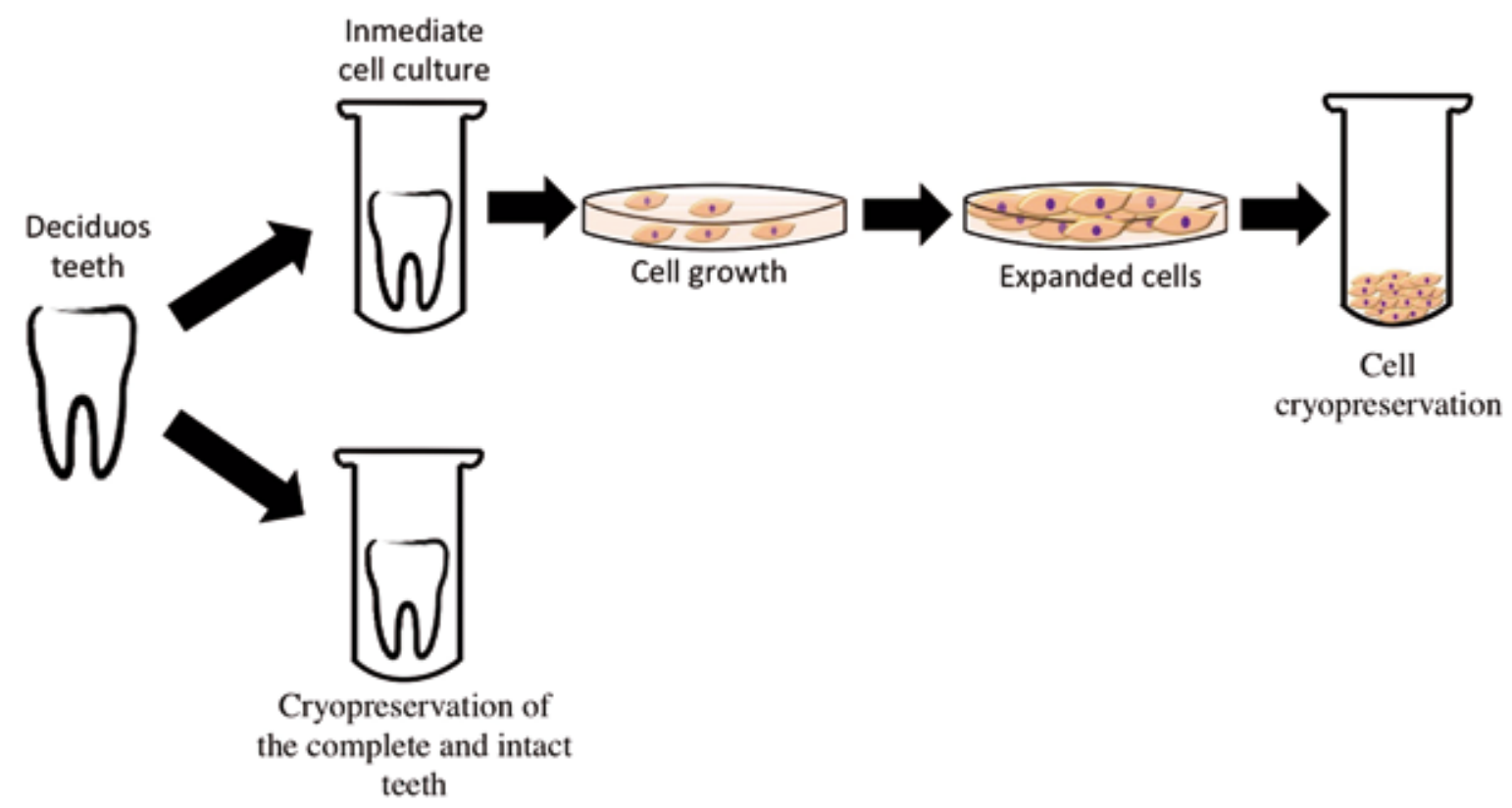

Fig. 2. Storage conditions of deciduous teeth up to the time of obtaining the MSCs. 
REGENERATION OF THE DENTIN-PULP COMPLEX

Preservation of dental pulp tissue and its viability are key factors that prevent the loss of dental organs. Tissue engineering approaches are based on the search for strategies to establish more predictable evidence of the processes of revascularization of the pulp-dentin complex. DPSC constructs shows promise for the regeneration of pulpal tissue and are safe and efficacious for complete pulp regeneration $(27,28)$.

Studies have reported the possible regeneration of pulp tissue from a combination of DPSC and platelet-rich plasma in animal models $(29,30)$. The design and synthesis of the nanofibrous microsphere-scaffolding system, loaded with growth factors such as Vascular Endothelial Growth Factor (VEGF) with heparin and DPSC in vivo have demonstrated the successful regeneration of tissues similar to those of dental pulp, permitting the regeneration of blood vessels (31). The search to establish this type of strategy, which promotes revascularization of the neoformed tissue comprises one of the greatest problems. A favorable microenvironment that promotes cell-cell interaction is required. It has been demonstrated that Human Umbilical Vein Endothelial Cells (HUVEC) and DPSC are cells capable of depositing an extracellular matrix that favors angiogenesis, and increase early vascular network formation by facilitating the migration of HUVEC and increasing the expression of VEGF (32). Transplantation of DPSC under conditions containing Human Serum (HS) has shown the regeneration of pulp tissue by its differentiation into endothelial cells to participate in the formation of the angiogenesis and regeneration of dentin processes (33).

On the other hand, dentin repair is a highly complex biological process, involving the repair of a most mineralized tissue in the human body (34). It is composed of approximately
$65 \%$ inorganic material by weight, and the vast majority of this material is present in the form of hydroxyapatite crystals. Porcine Deciduous Pulp Stem Cells (PDPSC) have been mixed with beta TriCalcium-Phosphate scaffolds ( $\beta$-TCP) for dentin regeneration in pulp-chamber roof defects in pig premolars, demonstrating preclinical evidence of regeneration in structures similar to that of dentin in the pulp chamber (35). The ability of zinc loaded nanogels to promote dentin mineralization comprises a possible therapeutic option for cervical regeneration of dentin and treatment of dentin hypersensitivity (36). Attempts have been made to establish an in-vivo protocol for pulp tissue engineering employing the implantation of bone-marrow MSC into biodegradable scaffolds as hydrogels in molar pulpotomies in rat models (37). For in-vivo study, the human-tooth root canal has been filled with DPSC in constructs, demonstrating the formation of pulpal tissue with rich blood vessels within the human root canal 6 weeks after implantation (38).

\section{REGENERATION OF THE PERIODONTIUM}

Periodontal regeneration requires a strategy that allows new fixation of the connective tissue to the root surface, a complex process for the tissues in that it involves the formation of new cement on the root surface. It has been identified that PDLSC are a type of stem cell present in periodontal tissues and that are capable of differentiating into cement forming cells and osteoblasts (39). On the other hand, PDLSC have been reported to possess the capacity to form a cementum $(9$, 40) and that, on being inoculated into scaffolds of $\beta$-TCP/collagen, they serve as a promising tool for periodontal regeneration (41). DPSC of allogeneic origin have been used in regenerative periodontal therapy in bone defects (42) and in the regenerative treatment of deep intrabody defects (43).

It is known that the extracellular environment surrounding the cells consists of a compartment 
in which the molecules are dissolved, and this contains a matrix of polysaccharides and proteins that give shape to the tissues. If this extracellular microenvironment is damaged, it will affect the proliferation and differentiation of the cells found there. It was previously demonstrated that an affected periodontal microenvironment causes the decrease of the osteogenic and cementogenic abilities of the cells. In contrast, a favorable microenvironment, which can be provided by conditioned means secreted by cells, can increase the proliferation and differentiation of PDLSC (44). Conditioned media are obtained from cell cultures that contain cell secretions such as peptides, paracrine factors, components of the extracellular matrix (45). It has been demonstrated that conditioned media obtained from dental-follicle cells can stimulate the behavior of periodontalligament fibroblasts (46), and that defects treated with PDLSC exhibited a significantly greater percentage of bone-filling and new bone-bridge length compared with synthetic materials (47).

\section{AUTOGENOUS SOURCE OF DENTAL ORGANS FOR THE REGENERATION OF BONE TISSUE}

In some patients, tooth extraction is required prior to dental implant treatment and these teeth are usually discarded. It would be beneficial if they could be used as autogenous graft material. Currently, protocols and techniques have been developed for the processing of materials utilized as bone grafts from teeth extracted from the patient. Based on these studies, we can anticipate the development of biomaterials for regenerative and dental restoration employing extracted teeth (48). The tooth is a structure formed by inorganic components such as calcium phosphate and by organic components such as collagen. Teeth and bone tissues share many similarities, since the teeth, cartilage, nerves, and maxillofacial bones originate embryologically in the neural crest, sharing an identical origin. It is well known that the structure and composition of dentin is similar to that of bone, which consists of $20 \%$ collagen, $70 \%$ hydroxyapatite, and 10\% fluid (49). Bone grafts of autologous teeth have been developed from extracted teeth, from a third molar or from a nonrestorable tooth, extraction of the tooth is performed and the latter subjected to a demineralization process. In-vitro and in-vivo studies have shown that demineralized dentin (DD) possesses osteoinductive and osteoconductive properties. The osteoinductive and autogenous properties of DDM in bone defects of rabbit mandibles have demonstrated complete incorporation of DDM into the newly formed bone tissue (50).

\section{CONCLUSIONS}

Innovations in regenerative medicine and tissue engineering have allowed conventional treatments to evolve in order to increase the expectations of success in the therapeutic options of dental treatments seeking to restore or regenerate lost or damaged tissue function. The applications of MSC obtained from dental structures have demonstrated their successful transplantation in an injectable manner at the site of the defect site or inoculated into biomaterials. Continuous in-vitro research and future in-vivo tests will permit that in the future, the performance of these therapeutic options in the dental office in a conventional manner. DPSC are promising cells for the regeneration of bone, pulp, and dentin tissues because they permit induction to biological processes, due to their behavior and cellular activity.

\section{REFERENCES}

1. Langer R., Vacanti J. P. Tissue engineering. Science. 1993; 260 (5110): 920-6.

2. Li W. J., Tuli R., Okafor C., Derfoul A., Danielson K. G., Hall D. J., et al. A three- 
dimensional nanofibrous scaffold for cartilage tissue engineering using human mesenchymal stem cells. Biomaterials. 2005; 26 (6): 599-09.

3. Mason C., Dunnill P. A brief definition of regenerative medicine. Regen Med. 2008; 3: 1-5.

4. Payne K. F., Balasundaram I., Deb S., Di Silvio L., Fan K. F. Tissue engineering technology and its possible applications in oral and maxillofacial surgery. Br J Oral Maxillofac Surg. 2014; 52 (1): 7-15.

5. Miran S., Mitsiadis T.A., Pagella P. Innovative dental stem cell-based research approaches: The future of dentistry. Stem Cells Int. 2016; doi.org/10.1155/2016/7231038

6. Gronthos S., Mankani M., Brahim J., Robey P. G., Shi S. Postnatal human dental pulp stem cells (DPSCs) in vitro and in vivo. Proc Natl Acad Sci. 2000; 97(25): 13625-30.

7. Gronthos S., Brahim J., Li W., Fisher L. W., Cherman N., Boyde A., et al. Stem cell properties of human dental pulp stem cells. J Dent Res. 2002; 81 (8): 531-5.

8. Sonoyama W., Liu Y., Fang D., Yamaza T., Seo B. M., Zhang C. Mesenchymal stem cell-mediated functional tooth regeneration in swine. PloS One. 2006; doi.org/10.1371/ journal.pone.0000079

9. Seo B. M., Miura M., Gronthos S., Bartold P. M., Batouli S., Brahim J., et al. Investigation of multipotent postnatal stem cells from human periodontal ligament. Lancet. 2004; 364 (9429): 149-55.

10. Morsczeck C., Götz W., Schierholz J., Zeilhofer F., Kühn U., Möhl C., et al. Isolation of precursor cells (PCs) from human dental follicle of wisdom teeth. Matrix Biol. 2005; 24 (2): 155-65.

11. Musumeci G., Castrogiovanni P., Leonardi R., Trovato F. M., Szychlinska M. A., Di Giunta A., et al. New perspectives for articular cartilage repair treatment through tissue engineering: A contemporary review. World J Orthop. 2014; 5 (2): 80-8.
12. Leach J. K., Whitehead J. Materials-directed differentiation of mesenchymal stem cells for Tissue Engineering and Regeneration. ACS Biomater Sci Eng. 2018; 9; (4): 1115-27.

13. Fujii Y., Kawase K. Y., Hojo H., Yano F., Sato M., Chung U. I., et al. Bone regeneration by human dental pulp stem cells using a helioxanthin derivative and cell-sheet technology. Stem Cell Res Ther. 2018; 9 (1): 24.

14. Tomasello L., Mauceri R., Coppola A., Pitrone M., Pizzo G., Campisi G., et al. Mesenchymal stem cells derived from inflamed dental pulpal and gingival tissue: a potential application for bone formation. Stem Cell Res Ther. 2017; 8 (1): 179.

15. Kouhestani F., Dehabadi F., Hasan S. M., Motamedian S. R. Allogenic vs. synthetic granules for bone tissue engineering: an in vitro study. Prog Biomater. 2018; 7 (2): 133-41.

16. Houshmand B., Tabibzadeh Z., Motamedian S. R., Kouhestani F. Effect of metformin on dental pulp stem cells attachment, proliferation and differentiation cultured on biphasic bone substitutes. Arch Oral Biol. 2018; 18; 95: 44-50.

17. Yasui T., Mabuchi Y., Morikawa S., Onizawa K., Akazawa C., Nakagawa T., et al. Isolation of dental pulp stem cells with high osteogenic potential. Inflamm Regen. 2017; 10; 37:8.

18. Fernandes T. L., Shimomura K., Asperti A., Pinheiro C. C. G., Caetano H. V. A., Oliveira C. R. G. C. M. Development of a novel large animal model to evaluate human dental pulp stem cells for articular cartilage treatment. Stem Cell Rev. 2018; 14(5): 734-43.

19. Lei M., Li K., Li B., Gao L. N., Chen F. M., Jin Y. Mesenchymal stem cell characteristics of dental pulp and periodontal ligament stem cells after in vivo transplantation. Biomaterials. 2014; 35 (24): 6332-43.

20. Asutay F., Polat S., Gül M., Subaşı C., Kahraman S. A., Karaöz E. The effects of dental pulp stem cells on bone regeneration in rat calvarial defect model: Micro-computed 
tomography and histomorphometric analysis. Arch Oral Biol. 2015; 60 (12): 1729-35.

21. Bottino M. C., Yassen G. H., Platt J. A., Labban N., Windsor L. J., Spolnik K. J., et al. A novel three-dimensional scaffold for regenerative endodontics: materials and biological characterizations. J Tissue Eng Regen Med. 2015; 9 (11): 116-23.

22. Chamieh F., Collignon A. M., Coyac B. R., Lesieur J., Ribes S., Sadoine J., et al. Accelerated craniofacial bone regeneration through dense collagen gel scaffolds seeded with dental pulp stem cells. Sci Rep. 2016; 9;6: 38814.

23. Kerkis I., Caplan A. I. Stem cells in dental pulp of deciduous teeth. Tissue Eng Part B Rev. 2012; 18 (2): 129-38.

24. Gioventù S., Andriolo G., Bonino F., Frasca S., Lazzari L., Montelatici E., et al. Novel method for banking dental pulp stem cells. Transfus Apher Sci. 2012 Oct; 47 (2): 199-206.

25. Kim Y. K., Kim S. G., Byeon J. H., Lee H. J., Um I. U., Lim S. C., et al. Development of a novel bone grafting material using autogenous teeth. Oral Surg Oral Med Oral Pathol Oral Radiol Endod. 2010; 109 (4): 496-503.

26. Lee H. S., Jeon M., Kim S. O., Kim S. H., Lee J. H., Ahn S. J., et al. Characteristics of stem cells from human exfoliated deciduous teeth (SHED) from intact cryopreserved deciduous teeth. Cryobiology. 2015; 71 (3): 374-83.

27. Huang G. T., Al-Habib M., Gauthier P. Challenges of stem cell- based pulp and dentin regeneration: A clinical perspective. Endod Topics. 2013; 28 (1): 51-60.

28. Itoh Y., Sasaki J. I., Hashimoto M., Katata C., Hayashi M., Imazato S. Pulp Regeneration by 3-dimensional dental pulp stem cell constructs. J Dent Res. 2018; 97 (10): 1137-43.

29. Nakashima M., Iohara K., Murakami M., Nakamura H., Sato Y., Ariji Y., et al. Pulp regeneration by transplantation of dental pulp stem cells in pulpitis: a pilot clinical study. Stem Cell Res Ther. 2017; 8 (1):61.

30. Zhu W., Zhu X., Huang G. T., Cheung G. S., Dissanayaka W. L., Zhang C. Regeneration of dental pulp tissue in immature teeth with apical periodontitis using platelet-rich plasma and dental pulp cells. Int Endod J. 2013; 46 (10): 962-70.

31. Li X., Ma C., Xie X., Sun H., Liu X. Pulp regeneration in a full-length human tooth root using a hierarchical nanofibrous microsphere system. Acta Biomater. 2016; 35: 57-67.

32. Dissanayaka W. L., Hargreaves K. M., Jin L., Samaranayake L. P., Zhang C. The interplay of dental pulp stem cells and endothelial cells in an injectable peptide hydrogel on angiogenesis and pulp regeneration in vivo. Tissue Eng Part A. 2015; 21 (3-4): 550-63.

33. Piva E., Tarlé S. A., Nör J. E., Zou D., Hatfield E., Guinn T., et al. Dental pulp tissue regeneration using dental pulp stem cells isolated and expanded in human serum. J Endod. 2017; 43 (4): 568-74.

34. Cao Y., Song M., Kim E., Shon W., Chugal N., Bogen G., et al. Pulp-dentin regeneration: current state and future prospects. J Dent Res. 2015; 94 (11): 1544-51.

35. Zheng Y., Wang X. Y., Wang Y. M., Liu X. Y., Zhang C. M., Hou B. X., et al. Dentin regeneration using deciduous pulp stem/ progenitor cells. J Dent Res. 2012; 91 (7): 676-82.

36. Toledano M., Cabello I., Osorio E., Aguilera F. S., Medina C. A. L., Toledano O. M. Zncontaining polymer nanogels promote cervical dentin remineralization. Clin Oral Investig. 2018; doi:10.1007/s00784-018-2548-1

37. Kaneko T., Gu B., Sone P. P., Zaw S. Y. M., Murano H., Zaw Z. C. T., et al. Dental Pulp Tissue Engineering Using Mesenchymal Stem 
Cells: a Review with a Protocol. Stem Cell Rev. 2018; doi.org/10.1007/s12015-018-9826-9

38. Itoh Y., Sasaki J. I., Hashimoto M., Katata C., Hayashi M., Imazato S. Pulp Regeneration by 3-dimensional Dental Pulp Stem Cell Constructs. J Dent Res. 2018; doi:10.1177/0022034518772260

39. Hernández M. B., Santiago O. E., Monroy G. A., Ledesma M. E., Mendoza N. V. M. Mesenchymal stem cells of dental origin for inducing tissue regeneration in periodontitis: A mini-review. Int J Mol Sci. 2018; 22; 19 (4).

40. Menicanin D., Mrozik K. M., Wada N., Marino V., Shi S., Bartold P. M. Periodontalligament- derived stem cells exhibit the capacity for long-term survival, self-renewal, and regeneration of multiple tissue types in vivo. Stem Cells Dev. 20141; 23 (9): 1001-11.

41. Tsumanuma Y., Iwata T., Washio K., Yoshida T., Yamada A., Takagi R., et al. Comparison of different tissue-derived stem cell sheets for periodontal regeneration in a canine 1-wall defect model. Biomaterials. 2011; 32 (25): 5819-25.

42. Hernández M. B., Santiago O. E., Ledesma M. E., Alcauter Z. A., Mendoza N. V. M. Retrieval of a periodontally compromised tooth by allogeneic grafting of mesenchymal stem cellsfrom dental pulp: A case report. J Int Med Res. 2018; 46 (7): 2983-93.

43. AimettiM., FerrarottiF., Gamba M. N., Giraudi M., Romano F. Regenerative treatment of periodontal intrabony defects using autologous dental pulp stem cells: A 1-year follow-up case series. Int $\mathrm{J}$ Periodontics Restorative Dent. 2018; 38 (1): 51-58.
44. Zhang J., An Y., Gao L. N., Zhang Y. J., Jin Y., Chen F. M. The effect of aging on the pluripotential capacity and regenerative potential of human periodontal ligament stem cells. Biomaterials. 2012; 33 (29): 6974-86.

45. Nagata M., Iwasaki K., Akazawa K., Komaki M., Yokoyama N., Izumi Y., et al. Conditioned medium from periodontal ligament stem cells enhances periodontal regeneration. Tissue Eng Part A. 2017; 23 (9-10): 367-77.

46. Liu J., Wang L., Liu W., Li Q., Jin Z., Jin Y. Dental follicle cells rescue the regenerative capacity of periodontal ligament stem cells in an inflammatory microenvironment. PLoS One. 2014; 9 (10): 108752.

47. Han J., Menicanin D., Marino V., Ge S., Mrozik K., Gronthos S., et al. Assessment of the regenerative potential of allogeneic periodontal ligament stem cells in a rodent periodontal defect model. J Periodontal Res. 2014; 49 (3): 333-45.

48. Kim Y. K., Lee J., Um I. W., Kim K. W., Murata M., Akazawa T., et al. Tooth-derived bone graft material. J Korean Assoc Oral Maxillofac Surg. 2013; 39 (3): 103-11.

49. Stevens A., Zuliani T., Olejnik C., LeRoy H., Obriot H., Kerr-Conte J., et al. Human dental pulp stem cells differentiate into neural crestderived melanocytes and have label-retaining and sphere-forming abilities. Stem Cells Dev. 2008; doi: 10.1089/scd.2008.0012

50. Kim Y. K., Kim S. G., Yun P. Y., Yeo I. S., Jin S. C., Oh J. S., et al. Autogenous teeth used for bone grafting: a comparison with traditional grafting materials. Oral Surg Oral Med Oral Pathol Oral Radiol. 2014; 117 (1): 39-45. 